\title{
Editorial
}

Journal of Innate

Immunity

\section{Unexpected and Novel Functions of Complement Proteins}

Complement activation was probably one of the first observations in humoral innate immunity and this field of research would not have been evolved without the pioneering work of Jules Bordet (1870-1961) [1]. Bordet, who started his scientific career in Metchnikoff s lab at the Pasteur Institute, discovered that, apart from a cellular immune response (phagocytosis), serum also has the ability to kill bacteria. In recognition of these findings, Bordet was awarded the Nobel Prize in Physiology or Medicine 'for his discoveries relating to immunity' as early as 1919. Today, our knowledge about the complement system has advanced enormously and, with the discovery of the lectin pathway [2], it was thought that its role in innate immunity was completely unraveled. However, as with many other areas in life science, recent discoveries point to additional roles for the complement system in various pathophysiological processes, including rheumatic diseases and organ transplantation $[3,4]$, making the complement system an interesting therapeutic target in drug discovery $[5,6]$. Thus, within the last couple of years, Journal of Innate Immunity has published several articles dealing with different functions of the complement system, such as its role in inflammation [7], agerelated macular degeneration [8], chronic renal failure [9] and the lectin pathway [10], as well as its interactions with eukaryotic cells [11-14] and microbial pathogens [1517].

In this issue of Journal of Innate Immunity, Uday Kishore, Kenneth B.M. Ried and Robert B. Sim have edited a thematic focus section entitled 'Unexpected and Novel Functions of Complement Proteins'. The section consists of three articles published by outstanding researchers in the field. The review by Alex Langford-Smith and his colleagues [8] presents a timely overview on the role of complement in macular degeneration. The article summarizes the recent findings on the role of complement factor $\mathrm{H}$ on eye inflammation which show that polymorphism in protein factor $\mathrm{H}$ has a significant impact on the development of age-related macular degeneration. The reader will learn that this affects the interaction of factor $\mathrm{H}$ with heparin sulfate, which in turn contributes to chronic eye inflammation. The other two contributions are original research articles. Mélanie Verneret and coworkers [18] show that complement factor $\mathrm{Clq}$ interacts with surface-exposed calreticulin on early apoptotic cells. The authors describe that this leads to an important role of $\mathrm{Clq}$ in regulating the inflammatory responses of dying cells. Joseph O'Flynn and collaborators [14] are also working with phagocytes. In their article it was found that several neutrophil-derived proteins, including myeloperoxidase, elastase, lysozyme and cathepsin G, interact with properdin, a member of the alternative part of the complement system. Interestingly, only the interaction with myeloperoxidase leads to a subsequent activation of the complement system as measured by C5b-9 deposition. Together, these articles show that the complement system still bears many unknown sides that need to be discovered and will enhance our knowledge of one of the first-reported humoral parts of the innate immune system.

Heiko Herwald, Lund Arne Egesten, Lund 


\section{References}

$>1$ Dworkin J, Tan SY: Jules Bordet (1870-1961): pioneer of immunology. Singapore Med J 2013;54:475-476.

-2 Thiel S, Vorup-Jensen T, Stover CM, Schwaeble W, Laursen SB, Poulsen K, Willis AC, Eggleton P, Hansen S, Holmskov U, Reid KB, Jensenius JC: A second serine protease associated with mannan-binding lectin that activates complement. Nature 1997;386:506-510.

-3 Sturfelt G, Truedsson L: Complement in the immunopathogenesis of rheumatic disease. Nat Rev Rheumatol 2012;8:458-468.

$\checkmark 4$ Sacks SH, Zhou W: The role of complement in the early immune response to transplantation. Nat Rev Immunol 2012;12:431-442.

$\checkmark 5$ Wagner E, Frank MM: Therapeutic potential of complement modulation. Nat Rev Drug Discov 2010;9:43-56.

-6 Zipfel PF, Skerka C: Complement regulators and inhibitory proteins. Nat Rev Immunol 2009;9:729-740.

$\checkmark 7$ Francescut L, Steiner T, Byrne S, Cianflone K, Francis S, Stover C: The role of complement in the development and manifestation of murine atherogenic inflammation: novel avenues. J Innate Immun 2012;4:260-272.
8 Langford-Smith A, Keenan TDL, Clark SJ, Bishop PN, Day AJ: The role of complement in age-related macular degeneration: heparan sulphate, a ZIP code for complement factor H? J Innate Immun 2014;6:407-416.

$>9$ Satomura A, Fujita T, Yanai M, Kumasaka K, Uehara Y, Okada K, Fuke Y, Nakayama T: Functional mannose-binding lectin levels in patients with end-stage renal disease on maintenance hemodialysis. J Innate Immun 2012;4:293-300.

10 Ma YJ, Skjoedt MO, Garred P: Collectin-11/ MASP complex formation triggers activation of the lectin complement pathway - the fifth lectin pathway initiation complex. J Innate Immun 2013;5:242-250.

-11 Moghimi SM, Parhamifar L, Ahmadvand D, Wibroe PP, Andresen TL, Farhangrazi ZS, Hunter AC: Particulate systems for targeting of macrophages: basic and therapeutic concepts. J Innate Immun 2012;4:509-528.

12 McCormack R, de Armas LR, Shiratsuchi M, Ramos JE, Podack ER: Inhibition of intracellular bacterial replication in fibroblasts is dependent on the perforin-like protein (perforin-2) encoded by macrophage-expressed gene 1. J Innate Immun 2013;5:185-194.

13 Kretschmer D, Nikola N, Durr M, Otto M, Peschel A: The virulence regulator Agr controls the staphylococcal capacity to activate human neutrophils via the formyl peptide receptor 2 . J Innate Immun 2012;4:201-212.
4 O’Flynn J, Dixon KO, Faber Krol MC, Daha MR, van Kooten C: Myeloperoxidase directs properdin-mediated complement activation. J Innate Immun 2014;6:417-425.

-15 Jongerius I, von Kockritz-Blickwede M, Horsburgh MJ, Ruyken M, Nizet V, Rooijakkers SH: Staphylococcus aureus virulence is enhanced by secreted factors that block innate immune defenses. J Innate Immun 2012;4: 301-311.

-16 Conrad EC, Hsu YY, Bortz DM, Younger JG Spatiotemporal dynamics of complement C5a production within bacterial extracellular polymeric substance. J Innate Immun 2013;5: 114-123.

-17 Pan Q, Chen H, Wang F, Jeza VT, Hou W, Zhao Y, Xiang T, Zhu Y, Endo Y, Fujita T, Zhang XL: L-ficolin binds to the glycoproteins hemagglutinin and neuraminidase and inhibits influenza A virus infection both in vitro and in vivo. J Innate Immun 2012;4:312324.

18 Verneret M, Tacnet-Delorme P, Osman R, Awad R, Grichine A, Kleman J-P, Frachet P: Relative contribution of $\mathrm{Clq}$ and apoptotic cell-surface calreticulin to macrophage phagocytosis. J Innate Immun 2014;6:426434 